\title{
Ecological responses to elevated water temperatures across invasive populations of the round goby (Neogobius melanostomus) in the Great Lakes basin
}

\author{
Heather Bauer Reid and Anthony Ricciardi
}

\begin{abstract}
Climate warming is expected to alter the distribution, abundance, and impact of non-native species in aquatic ecosystems. In laboratory experiments, we measured the maximum feeding rate and critical thermal maximum $\left(\mathrm{CT}_{\mathrm{max}}\right)$ of an invasive Eurasian fish, the round goby (Neogobius melanostomus), acclimated to a range of temperatures $\left(18-28{ }^{\circ} \mathrm{C}\right)$ reflecting current and projected future thermal conditions for the nearshore Great Lakes. Fish were collected from four distinct populations along a latitudinal gradient from the western basin of Lake Erie to Hamilton Harbour (Lake Ontario) and the upper St. Lawrence River. Thermal tolerance increased with acclimation temperature for populations in Lakes Erie and Ontario. However, the St. Lawrence River populations had lower acclimation capacity and exhibited an unexpected decline in $\mathrm{CT}_{\max }$ at the highest acclimation temperature. Maximum feeding rates peaked at $18-24{ }^{\circ} \mathrm{C}$ and declined with temperatures above $24{ }^{\circ} \mathrm{C}$. Northern populations in the basin appear poorly adapted to elevated temperatures such that their performance and impact could be reduced by climate warming. Thermal response data from latitudinally distributed populations are needed to inform invasive species risk assessment.
\end{abstract}

Résumé : Le réchauffement climatique est appelé à modifier la répartition, l'abondance et l'impact des espèces non indigènes sur les écosystèmes aquatiques. Dans des expériences en laboratoire, nous avons mesuré le taux d'alimentation maximum et la température maximale critique $\left(\mathrm{CT}_{\max }\right)$ d'un poisson eurasien envahissant, le gobie à taches noires (Neogobius melanostomus), acclimaté à une fourchette de températures $\left(18-28^{\circ} \mathrm{C}\right)$ reflétant les conditions thermiques actuelles et futures projetées pour la zone littorale des Grands Lacs. Des poissons ont été prélevés de quatre populations distinctes le long d'un gradient latitudinal allant du bassin ouest du lac Érié au port de Hamilton (lac Ontario) et au cours supérieur du fleuve Saint-Laurent. La tolérance thermique augmente parallèlement à la température d'acclimatation pour les populations des lacs Érié et Ontario. Les populations du fleuve Saint-Laurent présentent toutefois une capacité d'acclimatation plus faible et une baisse non anticipée de la $\mathrm{CT}_{\max }$ à la température d'acclimatation la plus élevée. Les taux d'alimentation maximums culminent à $18-24{ }^{\circ} \mathrm{C}$ et diminuent à des températures supérieures à $24^{\circ} \mathrm{C}$. Les populations nordiques dans le bassin semblent mal adaptées à des températures élevées, de sorte que le réchauffement climatique pourrait réduire leur performance et leur impact. Des données sur les réactions aux conditions de température de populations à répartition latitudinale sont nécessaires pour éclairer l'évaluation des risques que posent les espèces envahissantes. [Traduit par la Rédaction]

\section{Introduction}

Climate change and invasive species are predominant among the stressors affecting freshwater systems around the world (Hellmann et al. 2008; Mainka and Howard 2010). Temperature is a fundamental environmental factor affecting all organisms, particularly ectotherms (Pörtner et al. 2006; Schulte 2015). For freshwater ectotherms, changing thermal regimes have varying consequences for individual performance (Huey and Stevenson 1979; Morrison et al. 2020). Performance can be evaluated using a variety of measures, including behaviour (e.g., thermal preferenda, feeding rates) and physiology (e.g., critical thermal maximum, acclimation response ratio), both of which are highly sensitive to climate change (Huey and Stevenson 1979; Abram et al. 2017; Drouillard et al. 2018). Performance at critical temperatures can be maintained by plastic responses (e.g., acclimation capacity) that buffer thermal stress (Schulte 2014; Rohr et al.
2018), and many species can adapt to changing thermal conditions (Hoffmann and Sgrò 2011; Schulte 2014).

A major concern is that non-native species will have physiological advantages over native species as temperatures increase, in part due to selection for broader tolerances and increased acclimation capacity (Kelley 2014). A changing climate will alter environmental filters that limit the establishment, persistence, population expansion, and competitive abilities of current and future invaders (Hellmann et al. 2008; Rahel and Olden 2008). However, forecasting the consequences of these shifting envinmental filters is hampered by understudied aspects of organismal biology (Kelley 2014; Robinson et al. 2017). In terms of their physiology and behaviour, different populations of the same species may respond differently to a changing climate (Chen et al. 2013; Radchuk et al. 2019). Across physical environmental gradients, the impacts and performance of a non-native species can differ considerably (Ricciardi

Received 27 May 2021. Accepted 1 July 2021.

H.B. Reid. Department of Biology, McGill University, 1205 Dr. Penfield Ave., Montréal, QC H3A 1B1, Canada; Redpath Museum, McGill University,

859 Sherbrooke Street West, Montréal, QC H3A 0C4, Canada.

A. Ricciardi. Redpath Museum, McGill University, 859 Sherbrooke Street West, Montréal, QC H3A 0C4, Canada.

Corresponding author: Anthony Ricciardi (email: tony.ricciardi@mcgill.ca).

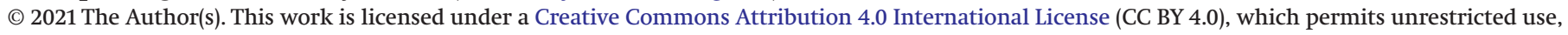
distribution, and reproduction in any medium, provided the original author(s) and source are credited. 
et al. 2013; Ricciardi et al. 2021). Such population-level responses are rarely compared, even across contiguous ranges such as the Great Lakes.

\section{The Great Lakes - St. Lawrence River basin}

The world's largest freshwater ecosystem, the Great Lakes St. Lawrence River basin, is characterized by overlapping anthropogenic stressors (Collingsworth et al. 2017) and heterogeneous climatic conditions (Bartolai et al. 2015). Climate change is driving altered patterns of precipitation, ice cover, water levels, and temperatures throughout the basin (Austin and Colman 2007; Bartolai et al. 2015). Lakes Erie and Ontario are the warmest of the Great Lakes, with mean summer surface water temperatures of 21 to $24{ }^{\circ} \mathrm{C}$ for Lake Erie and 18 to $22{ }^{\circ} \mathrm{C}$ for Lake Ontario, in recent decades (Mason et al. 2016; Collingsworth et al. 2017). In this century, climate change has been predicted to increase maximum temperatures in Lakes Erie and Ontario by at least 3.3 and $4.8{ }^{\circ} \mathrm{C}$, respectively, while even greater increases are predicted for the upper Great Lakes (Trumpickas et al. 2009). In addition, the Great Lakes - St. Lawrence River basin has been invaded by more than 180 non-native species (Ricciardi 2006), some of which have dramatically restructured food webs, contributed to biodiversity loss, and altered ecosystem function and services (Mills et al.1993). Among these is a benthic fish, the round goby (Neogobius melanostomus), which is the most invasive vertebrate in the basin (Kornis et al. 2012). Native to the freshwater margins of the Azov, Black and Caspian seas (Jude et al. 1992; Charlebois et al. 2001), the round goby was introduced to the Great Lakes and the Baltic Sea through ballast water discharge from ocean vessels circa 1990 (Jude et al. 1992; Corkum et al. 2004), and it is now well-established and locally dominant in all five Great Lakes as well as the St. Lawrence River (Kornis et al. 2012).

Owing to its successful proliferation and ecological impacts on two continents, the round goby is considered a model organism for invasion biology (Kornis et al. 2012; Adrian-Kalchhauser et al. 2020). Many studies have focused on its colonization potential (Florin et al. 2018), invasion strategies (Brandner et al. 2018) and impacts on native species and ecosystem function (Kipp and Ricciardi 2012; Burkett and Jude 2015). Despite continuing scientific and management interest in this species (reflected in a rising number of publications over time; Kornis et al. 2012; Adrian-Kalchhauser et al. 2020), several key aspects of its ecology remain understudied. There has been relatively little attention given to population trait differences within its invaded range, although numerous comparisons have been made between gobies at different stages of invasion. Findings suggest strong phenotypic plasticity, with gobies at the leading edge of an invasion being larger, bolder, and with increased competitive abilities in comparison with gobies from the core population (Myles-Gonzalez et al. 2015; Brandner et al. 2018). This phenotypic plasticity extends to well-established populations; Kornis et al. (2017) found that connected populations in and around Lake Michigan had diverged substantially in life history traits, likely owing to local environmental conditions. Populations also exhibit very little gene flow once established and have considerable genetic diversity across the Great Lakes - St. Lawrence River basin (Brown and Stepien 2009). The potential for local adaptation and phenotypic plasticity in populations throughout the basin appears high and could be implicated in their responses to climate change.

Few studies have examined the thermal ecology of the round goby. The thermal optimum for this species is generally reported as $25-26{ }^{\circ} \mathrm{C}$ (Kornis et al. 2012; Hatton et al. 2018); this statistic is based on a bioenergetics study that recorded maximal food consumption between 23 and $26{ }^{\circ} \mathrm{C}$, followed by a sharp decline in consumption at higher temperatures, for round gobies collected from western Lake Erie and Lake St. Clair (Lee and Johnson 2005). Another metric, the critical thermal maximum $\left(\mathrm{CT}_{\max }\right)$, is a widely used measure of thermal tolerance that allows for interand intraspecific comparisons (Becker and Genoway 1979; Beitinger et al. 2000). To date, only two studies have examined $\mathrm{CT}_{\max }$ in the round goby: Cross and Rawding (2009) reported a loss of righting response at $31.5^{\circ} \mathrm{C}$ for round gobies from Erie, Pennsylvania, acclimated to $15{ }^{\circ} \mathrm{C}$, whereas Christensen et al. (2021) measured $\mathrm{CT}_{\max }$ for round gobies in Denmark at temperatures between 10 and $28^{\circ} \mathrm{C}$.

Understanding population-level differences in the behaviour and physiology of invasive species, particularly in the context of climate change, is crucial to managing aquatic resources (Ricciardi et al. 2021). Here, we conduct a multi-population comparison along a latitudinal gradient in the Great Lakes - St. Lawrence River basin to examine temperature effects on the upper thermal tolerance and feeding behaviour of the round goby. We predicted that (i) $\mathrm{CT}_{\max }$ would increase with acclimation temperature for all populations, with lower $\mathrm{CT}_{\max }$ overall recorded for the northernmost populations (Fangue et al. 2006); and (ii) maximum feeding rates of higher-latitude populations would peak at lower temperatures than those of lower-latitude populations. Given the findings of Lee and Johnson (2005), we predicted that the peak would occur between 22 and $26^{\circ} \mathrm{C}$ for low-latitude populations and below $22^{\circ} \mathrm{C}$ for high-latitude populations.

\section{Materials and methods}

\section{Collection sites}

Populations at four sites in the lower Great Lakes and the St. Lawrence River were selected for this study (Fig. 1): Kingsville, Lake Erie $\left(42.026^{\circ} \mathrm{N}, 82.741^{\circ} \mathrm{W}\right)$, Hamilton Harbour, Lake Ontario $\left(43.300^{\circ} \mathrm{N}, 79.845^{\circ} \mathrm{W}\right)$, Melocheville, St. Lawrence River $\left(45.319^{\circ} \mathrm{N}\right.$, $\left.73.927^{\circ} \mathrm{W}\right)$, and Sorel-Tracy, St. Lawrence River $\left(46.051^{\circ} \mathrm{N}, 73.089^{\circ} \mathrm{W}\right)$. These locations were chosen to represent a latitudinal gradient, because there is considerable climatic variation across the basin (Bartolai et al. 2015; Mason et al. 2016). Therefore, these locations and their fish communities are likely to experience different trajectories of climate change (Trumpickas et al. 2009). Although round gobies have been recorded in western Lake Erie since 1990, and in Lake Ontario near the headwaters of the St. Lawrence River since 1998 (Charlebois et al. 2001; Kornis et al. 2012), they were not observed downstream in the St. Lawrence River near Cornwall until 2004 and were not sufficiently abundant to be detected at sites near Montréal (e.g., Melocheville) until 2006 (Kipp et al. 2012). Neighboring sites along the river downstream from Montréal (e.g., Sorel-Tracy) were likely invaded around the same time.

Dispersal across long distances between Lake Erie, Lake Ontario, and the St. Lawrence River locations is presumed to be minimal for established populations of round goby in recent years (Johansson et al. 2018), such that these populations have been largely isolated from each other for over a decade. Melocheville and Sorel-Tracy are separated by a shorter distance $(\sim 110 \mathrm{~km})$, but might still exhibit thermal differences and population variation. All collection sites were nearshore locations with low flow, allowing seines and minnow traps to be used to capture fish. Round gobies were collected from Kingsville in Lake Erie, and Hamilton Harbour in Lake Ontario, in July 2019, whereas those from the St. Lawrence River sites of Melocheville and Sorel-Tracy were collected in September 2019 and August 2020, respectively. Animal collections were conducted with approved permits from the Ministère des Forêts, de la Faune et des Parcs in Québec (SEG Nos.: 2019-04-08-005-0-S-P and 2020-04-08-002-0-S-P) and the Ministry of Natural Resources and Forestry in Ontario (License No. 1098235).

\section{Quantifying habitat temperatures}

Temperature loggers (model: Onset HOBO Pendant MX2201) were deployed in the spring and summer of 2020 to record and compare summer temperatures across the collection sites. Owing to accessibility issues, the Lake Ontario (Hamilton) loggers were deployed at Bayshore Park $\left(43.307^{\circ} \mathrm{N}, 79.831^{\circ} \mathrm{W}\right)$, approximately $2 \mathrm{~km}$ away from the collection site. Additional loggers were also deployed in Cootes Paradise Marsh $\left(43.274^{\circ} \mathrm{N}, 79.895^{\circ} \mathrm{W}\right)$, which is 
Fig. 1. Map of sampling sites from western Lake Erie (KV: Kingsville) and Lake Ontario (HH: Hamilton) to the upper St. Lawrence River (ME: Melocheville; ST: Sorel-Tracy). Figure was created using QGIS 3.10 (QGIS Development Team 2020). Light Gray Canvas base map from Esri, HERE, DeLorme, MapmyIndia, OpenStreetMap contributors, and the GIS user community.

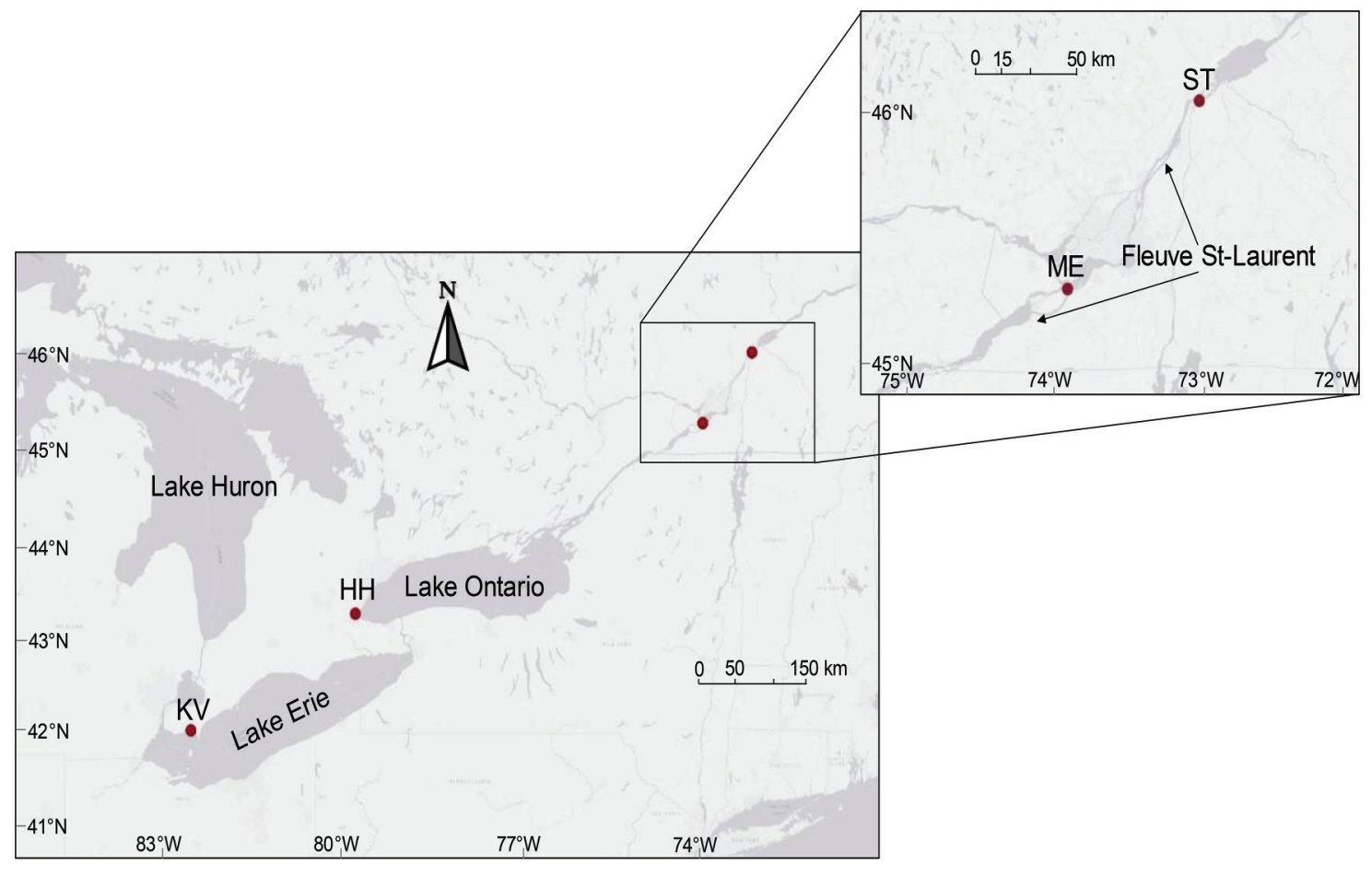

connected to Hamilton Harbour and contains high densities of the round goby (H.B.R., personal observation). This location is more sheltered than the collection sites and provided a comparison of temperatures between two nearby sites. Two loggers were zip-tied to a $4.5-\mathrm{kg}$ weight connected by rope to a float and placed at $\sim 1 \mathrm{~m}$ depth on flat substrate. All loggers recorded temperatures (to $0.5{ }^{\circ} \mathrm{C}$ resolution) once per hour during their period of deployment.

Logger data for Hamilton and Cootes Paradise spanned the period from 29 May to 27 September 2020, and data for Melocheville spanned 21 May to 30 September 2020. Owing to logistical issues in identifying suitable collection sites, loggers were deployed at Sorel-Tracy later in the summer, with temperature data collected between 28 July and 30 September 2020 . No data were available for Kingsville in Lake Erie as a consequence of logger loss; instead, water temperature data were obtained from the National Oceanic and Atmospheric Administration (NOAA) National Data Buoy Center (NDBC) for Station No. 45165 (ndbc.noaa.gov/station_page. php?station $=45165)$ outside Toledo, Ohio $\left(41.702^{\circ} \mathrm{N}, 83.261^{\circ} \mathrm{W}\right)$ and used as an approximation for Kingsville. The buoy measured water temperatures approximately $1 \mathrm{~m}$ below the surface in a nearshore location approximately $8 \mathrm{~m}$ deep. For this location, temperatures for the period between 21 May and 30 September 2020 were obtained. Mean daily temperatures were calculated for each site for each 24-h period between 29 May and 27 September, or 28 July and 27 September (for Sorel-Tracy). In addition, the absolute maximum and absolute minimum temperatures recorded were determined daily for each site. Records for two days are missing from the Melocheville and Sorel-Tracy datasets and one day is missing for Hamilton, owing to logger tampering.

\section{Holding and acclimation}

Round gobies from Kingsville and Hamilton were tested at the University of Toronto Scarborough campus, whereas fish from the St. Lawrence River populations were tested at McGill University. Following collection, round gobies were held in 75.7-L aquaria $(60.96 \mathrm{~cm} \times 30.48 \mathrm{~cm} \times 40.64 \mathrm{~cm})$ and acclimated to laboratory conditions for at least 7 days. For fish collected across populations, total lengths were $75-110 \mathrm{~mm}$ and weights were $4.90-18.25 \mathrm{~g}$. Owing to sampling constraints in the summer of 2020, adult fish collected from Sorel-Tracy tended to be smaller than individuals from other populations, although there was substantial overlap in size (see online Supplementary material, Table $S 1^{1}$ ). Fish from Lake Erie and Lake Ontario were initially acclimated at $21^{\circ} \mathrm{C}$, while those from Melocheville and Sorel-Tracy were acclimated at $18^{\circ} \mathrm{C}$. The photoperiod was maintained at $12 \mathrm{~h}$ light and $12 \mathrm{~h}$ dark. As the round goby is a cryptic species that prefers benthic cover (Jude et al.1992), aquaria were equipped with gravel and rock substrate and tube shelters (PVC pipe), as well as bubblers to maintain oxygen saturation. Water quality and fish mortality were monitored regularly. Fish were fed commercial pellets (Wardley Shrimp Pellets) daily.

Following the initial acclimation period, fish were moved to different 75.7-L aquaria and acclimated to one of four treatment temperatures $\left(18,22,26\right.$, or $\left.28^{\circ} \mathrm{C}\right)$. Aquaria were cooled to $18{ }^{\circ} \mathrm{C}$ at a rate of $1^{\circ} \mathrm{C}$ per day and thereafter held at $18{ }^{\circ} \mathrm{C}$ using chillers, for the two Great Lakes populations. Temperatures were increased by $1{ }^{\circ} \mathrm{C}$ per day (Stitt et al. 2014) in aquaria using heaters to reach 22, 26 , or $28{ }^{\circ} \mathrm{C}$. Temperatures were monitored and adjusted (as needed) daily. These temperatures were chosen to reflect a range of present and projected future summer temperatures in the lower Great Lakes (Trumpickas et al. 2009), with $18^{\circ} \mathrm{C}$ being below present means and $28{ }^{\circ} \mathrm{C}$ being above projected means. For the two St. Lawrence River populations (Melocheville and Sorel-Tracy), maximum feeding rates were tested at an additional temperature $\left(24^{\circ} \mathrm{C}\right)$. Aquarium temperatures throughout the acclimation period generally fell within $0.5{ }^{\circ} \mathrm{C}$ of the target. Fish were maintained at the treatment temperatures for 30 to 36 days, at the

${ }^{1}$ Supplementary data are available with the article at https://doi.org/10.1139/cjfas-2021-0141. 
Table 1. Mean $( \pm \mathrm{SE})$ weight $(\mathrm{g})$ and total length (TL; mm) of round goby used in feeding experiments, as well as the number tested for each population $\times$ acclimation temperature combination.

\begin{tabular}{llccl}
\hline $\begin{array}{l}\text { Acclimation } \\
\text { temperature }\left({ }^{\circ} \mathrm{C}\right)\end{array}$ & Population & $N$ & Mass $(\mathrm{g}) \pm \mathrm{SE}$ & $\mathrm{TL}(\mathrm{mm}) \pm \mathrm{SE}$ \\
\hline 18 & Kingsville & 5 & $8.43 \pm 0.62$ & $88 \pm 3.11$ \\
& Hamilton & 5 & $8.02 \pm 0.53$ & $85 \pm 2.06$ \\
& Melocheville & 7 & $9.87 \pm 1.18$ & $89 \pm 2.26$ \\
& Sorel-Tracy & 8 & $8.33 \pm 0.88$ & $87 \pm 2.44$ \\
& & & & \\
& Kingsville & 5 & $9.17 \pm 0.99$ & $89 \pm 3.44$ \\
& Hamilton & 5 & $10.21 \pm 1.42$ & $90 \pm 3.31$ \\
& Melocheville & 7 & $9.56 \pm 0.95$ & $89 \pm 2.57$ \\
& Sorel-Tracy & 7 & $6.74 \pm 0.61$ & $81 \pm 1.65$ \\
& & & & \\
& Melocheville & 7 & $10.47 \pm 1.59$ & $92 \pm 3.82$ \\
& Sorel-Tracy & 6 & $7.46 \pm 0.84$ & $83 \pm 2.76$ \\
& Kingsville & 6 & $8.21 \pm 0.86$ & $87 \pm 2.63$ \\
& Hamilton & 6 & $9.36 \pm 0.95$ & $92 \pm 2.56$ \\
& Melocheville & 7 & $9.51 \pm 0.55$ & $89 \pm 1.80$ \\
& Sorel-Tracy & 6 & $7.63 \pm 1.10$ & $86 \pm 3.89$ \\
& Kingsville & 5 & $8.43 \pm 1.03$ & $88 \pm 2.98$ \\
& Hamilton & 5 & $8.68 \pm 0.87$ & $87 \pm 2.92$ \\
& Melocheville & 6 & $9.20 \pm 1.19$ & $90 \pm 3.26$ \\
& Sorel-Tracy & 6 & $7.40 \pm 0.95$ & $84 \pm 3.56$ \\
\hline
\end{tabular}

end of which maximum feeding rate experiments were conducted. Animal care and experiments were conducted in accordance with accepted Canadian Council on Animal Care (CCAC) guidelines, with animal use protocols approved by the McGill Animal Care Committee (Protocol No. 2018-8004) and the University of Toronto Local Animal Care Committee (Protocol No. 20012427).

\section{Feeding behaviour and body condition}

We examined the maximum feeding rate of round gobies from each of the four collection locations at different temperatures. Feeding behaviour can serve as an indicator of the potential impact of predation and competition (David et al. 2017), and a high feeding rate is a common trait for high-impact invaders (Ricciardi et al. 2013). The feeding efficiency, and thus competitive ability, of an animal is closely tied to temperature (Huey and Stevenson 1979) and is expected to be maximal near the species' thermal optimum (Iacarella et al. 2015). Species that feed more at elevated temperatures could be favoured by climate change and have new or exacerbated impacts in their invaded range (Hellmann et al. 2008).

Individual fish were measured and weighed (Table 1), then were moved to isolated 37.9-L aquaria $(50.8 \mathrm{~cm} \times 25.4 \mathrm{~cm} \times$ $30.48 \mathrm{~cm}$ ) and allowed to acclimate for $24 \mathrm{~h}$, during which time they were not fed. These aquaria were maintained at the appropriate acclimation temperature $\left( \pm 0.8{ }^{\circ} \mathrm{C}\right)$ with a single shelter per aquarium. Following this acclimation period, a fixed number of prey items (225 thawed chironomid larvae, Chironomus sp., previously kept frozen; mean total mass of $1.3 \mathrm{~g}$ ) was introduced to each aquarium, and the fish were left for two hours to feed. This amount of prey exceeded what gobies were determined to be likely to consume in two hours (based on preliminary maximum feeding rate experiments), such that the amount of prey needed to satiate gobies in two hours could be determined. Prior to trial initiation, the filters in each aquarium were stopped to prevent the removal of prey from the aquarium via filtering, and bubblers were added to the aquaria to maintain oxygenation. Following the experimental time period, the fish were removed from the experimental aquarium and returned to their acclimation aquaria. The remaining prey items were then collected and counted to determine the number consumed.

From the length and weight measurements, body condition was also evaluated. Condition is commonly measured in aquaculture species, because it indicates fish fitness and can differ between populations kept under similar conditions (Bolger and Connolly 1989). The condition factor (K) was calculated using Fulton's index:

$$
K=100 \frac{W}{L^{3}}
$$

where $W$ is fish weight $(\mathrm{g})$ and $L$ is total length $(\mathrm{cm})$.

\section{Critical thermal maximum and acclimation capacity}

Round gobies from the same aquaria used in the maximum feeding rate experiments were used for $\mathrm{CT}_{\max }$ experiments, with at least a week between feeding trials and $\mathrm{CT}_{\max }$ testing. Fish were starved for $24 \mathrm{~h}$ prior to trial initiation. Five fish per acclimation temperature were used from each of the Kingsville and Hamilton populations, while six and seven fish from each acclimation temperature were tested from Sorel-Tracy and Melocheville, respectively. One to two fish from the same acclimation temperature and population were transferred to a 56.8-L aquarium $(60.96 \mathrm{~cm} \times 30.48 \mathrm{~cm} \times 30.48 \mathrm{~cm})$, with each fish placed in its own isolation box $(26.42 \mathrm{~cm} \times 15.24 \mathrm{~cm} \times 15.24 \mathrm{~cm})$ and an opaque divider placed between the two boxes to prevent the fish from seeing each other. Each isolation box had a tube shelter to provide potential refuge and reduce fish stress. The experimental aquarium was maintained at the acclimation temperature $\left( \pm 0.5^{\circ} \mathrm{C}\right)$, and fish were left to acclimate for $2 \mathrm{~h}$ to recover from handling stress. Constant aeration was provided to maintain oxygen saturation. Upon initiation of the trial, a JULABO CORIO CD heating immersion circulator (Seelbach, Germany) was used to increase the aquarium temperature at a fixed rate similar to the commonly recommended rate of $0.3^{\circ} \mathrm{C} \cdot \mathrm{min}^{-1}$ (Becker and Genoway 1979), except that the volume of the aquarium limited the heating rate to a slightly lower rate of $0.26{ }^{\circ} \mathrm{C} \cdot \mathrm{min}^{-1}$. The temperature was constantly monitored and recorded throughout the experiment using JULABO EasyTEMP Professional software. To minimize disturbance, fish were monitored during the acclimation period and the trial using a webcam.

In general, during the acclimation period and when a trial first began, the fish remained at the bottom of the breeding box and moved very little. After a period of time ( 10-40 min, depending on the starting temperature), the fish would begin moving around the box and eventually swim closer to the surface and push at the sides of the box. Trials continued with increasing temperature until fish stopped moving as frequently and eventually lost equilibrium, at which point the temperature was recorded as $\mathrm{CT}_{\max }$ (Carline and Machung 2001). Owing to the round goby's lack of a swim bladder (Kornis and Vander Zanden 2010), equilibrium had to be evaluated manually. When temperatures reached a point at which fish had elevated breathing rates and tended to remain still, equilibrium loss was assessed by gently turning the fish over with a probe; when the fish could no longer right itself after $5 \mathrm{~s}$, it was considered to have lost equilibrium (Carline and Machung 2001; Matern 2001). After reaching this endpoint, gobies were transferred to an aerated holding container and their recovery was evaluated. Once the trial was concluded, the fish were euthanized with eugenol and then measured, weighed, and photographed. The acclimation response ratio (ARR), an index for evaluating the thermal acclimation capacity of organisms across temperatures (Claussen 1977), was also calculated for each population between 18 and $26^{\circ} \mathrm{C}$, as well as between 18 and $28^{\circ} \mathrm{C}$. ARR is defined as the slope of the linear regression between $\mathrm{CT}_{\max }$ and acclimation temperature (Morley et al. 2019), and can be calculated across a range of acclimation temperatures to evaluate thermal plasticity. 
Table 2. Temperature data for each of the four study sites in the lower Great Lakes and the St. Lawrence River from 28 July to 27 September 2020.

\begin{tabular}{|c|c|c|c|c|}
\hline Site & $\begin{array}{l}\text { Mean }( \pm S E) \text { daily } \\
\text { temperature }\left({ }^{\circ} \mathrm{C}\right)\end{array}$ & $\begin{array}{l}\text { Absolute } \\
\text { minimum }\left({ }^{\circ} \mathrm{C}\right)\end{array}$ & $\begin{array}{l}\text { Absolute } \\
\text { maximum }\left({ }^{\circ} \mathrm{C}\right)\end{array}$ & $\begin{array}{l}\text { No. of days } \\
\geq 25^{\circ} \mathrm{C} \text { mean }{ }^{\dagger}\end{array}$ \\
\hline Toledo* (Erie) & $23.57 \pm 0.34$ & 17.40 & 27.20 & 59 \\
\hline Hamilton (Ontario) & $22.29 \pm 0.34$ & 15.78 & 26.85 & 32 \\
\hline Melocheville (St. Lawrence) & $21.95 \pm 0.35$ & 17.16 & 26.60 & 9 \\
\hline Sorel-Tracy (St. Lawrence) & $21.08 \pm 0.42$ & 13.47 & 28.44 & 9 \\
\hline
\end{tabular}

Fig. 2. Mean daily temperatures $\left({ }^{\circ} \mathrm{C}\right.$ ) in the summer of 2020 for four study sites: Toledo (proxy for Kingsville; Lake Erie), Hamilton (Lake Ontario), Melocheville (St. Lawrence River) and Sorel-Tracy (St. Lawrence River). The dashed line represents $25^{\circ} \mathrm{C}$. [Colour online.]

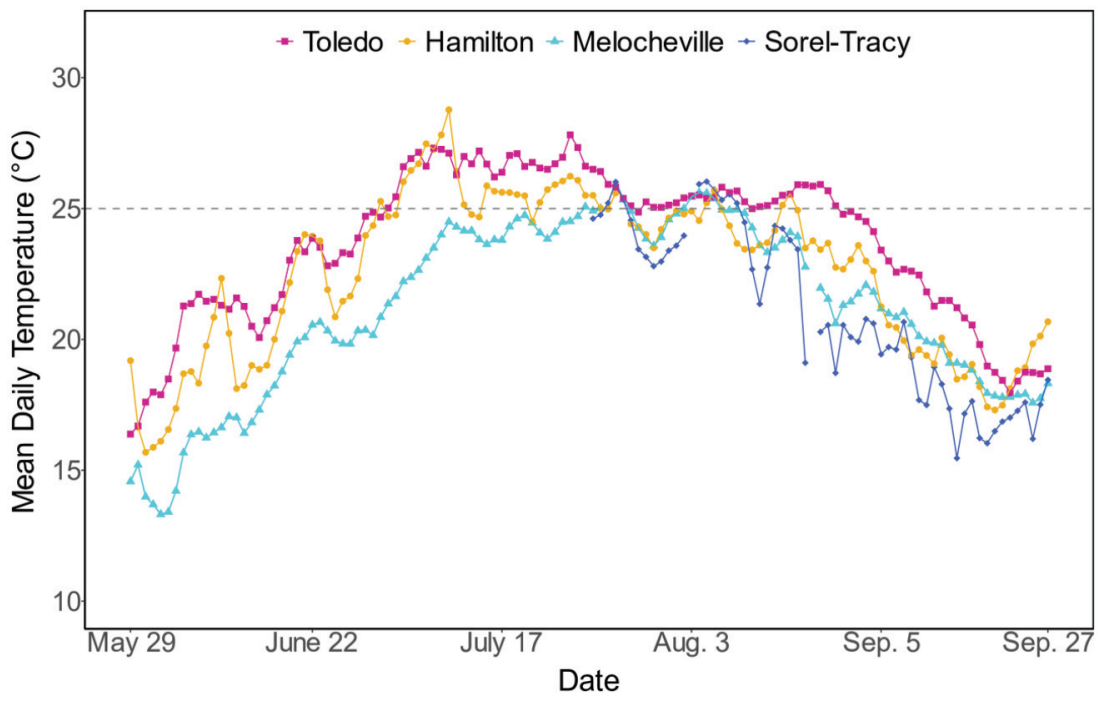

\section{Data analysis}

All data were analyzed using R v. 4.0.3 (R Core Team 2020). Habitat temperature data were compared visually to identify thermal patterns across sites. Differences in fish mass across populations were evaluated using a one-way analysis of variance (ANOVA) and subsequent multiple pairwise comparisons (glht function with Tukey option in R). A generalized additive model (GAM) approach was used to account for non-linear relationships observed between acclimation temperature and $\mathrm{CT}_{\max }$, feeding rate, or body condition. GAMs were built with a Gaussian distribution and an identity link function using the $\mathrm{mgcv}$ package in $\mathrm{R}$. All models were fit with the REML (restricted maximum likelihood) method. Smooth functions of acclimation temperature were included in all GAM models, with factor-smooth interactions so that smooths could differ by population. Population was included as a categorical explanatory variable. Fish mass was examined as a predictor for maximum feeding rate and $\mathrm{CT}_{\max }$ models, and sex was examined as a predictor in all three models; both predictors were determined to only contribute to maximum feeding rate results, so they were only included in the final maximum feeding rate model. Maximum feeding rate data were not standardized by fish mass for analysis so that the effect of mass could be evaluated using a smooth function with factor-smooth interactions by population. The best-fitting models were selected using Akaike's information criterion (AIC) scores; all models were evaluated using normal Q-Q plots, histograms of the residuals, plots of residuals and responses versus fitted values, and Shapiro-Wilk tests.

\section{Results}

Thermal responses varied across populations, most notably between northern (Melocheville and Sorel-Tracy) and southern (Kingsville and Hamilton) locations. Following expected latitudinal patterns, summer surface water temperatures differed considerably across collection sites (Table 2; Fig. 2; also see Supplementary Data Section $2^{1}$ ). Fish mass differed significantly across populations (oneway ANOVA: $F=4.99, p<0.01$ ), but pairwise comparisons found that a significant difference in weight occurred only between the two northernmost populations: Melocheville and Sorel-Tracy.

\section{Critical thermal maximum and acclimation capacity}

$\mathrm{CT}_{\max }$ varied significantly in relation to acclimation temperature and population (Table 3), and thermal tolerance generally increased with acclimation temperature (Fig. 3). $\mathrm{CT}_{\max }$ for Kingsville and Hamilton gobies increased from a mean \pm SE of $33.39 \pm$ $0.22{ }^{\circ} \mathrm{C}$ and $33.25 \pm 0.22{ }^{\circ} \mathrm{C}$, respectively, when acclimated to $18{ }^{\circ} \mathrm{C}$, up to $36.35 \pm 0.37^{\circ} \mathrm{C}$ and $36.70 \pm 0.23^{\circ} \mathrm{C}$, respectively, when acclimated to $28{ }^{\circ} \mathrm{C}$ (Supplementary Table S2 ${ }^{1}$ ). Round gobies from Melocheville and Sorel-Tracy also exhibited increases in $\mathrm{CT}_{\max }$ until $26{ }^{\circ} \mathrm{C}$, but then their $\mathrm{CT}_{\max }$ remarkably declined 
Fig. 3. Critical thermal maximum $\left({ }^{\circ} \mathrm{C}\right)$ for four populations of round goby acclimated to $18,22,26$ or $28{ }^{\circ} \mathrm{C}$. Ribbons represent \pm 2 standard errors around the mean, derived from GAM analysis.

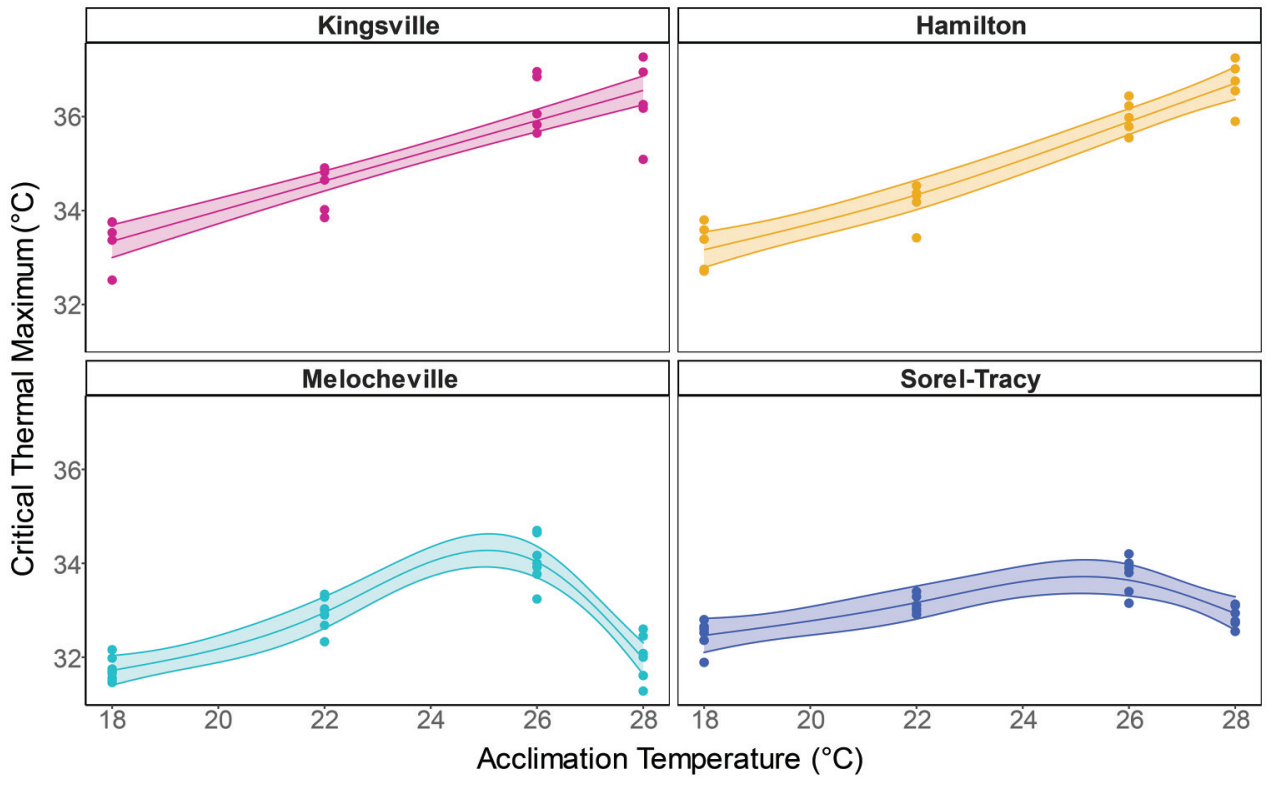

Table 3. Results of a generalized additive model (GAM) testing the effects of acclimation temperature and population on critical thermal maximum $\left(\mathrm{CT}_{\max }\right)$ of the round goby.

\begin{tabular}{llll}
\hline Parametric term & df & F & $p$ value \\
\hline Population & 3 & 183.800 & $<0.001$ \\
\hline Smooth terms & edf & \multicolumn{1}{l}{ F } & $p$ value \\
\hline (Temperature) $\times$ Kingsville & 1.000 & 147.061 & $<0.001$ \\
$s$ (Temperature) $\times$ Hamilton & 1.759 & 85.962 & $<0.001$ \\
$s$ (Temperature) $\times$ Melocheville & 2.956 & 38.616 & $<0.001$ \\
$s$ (Temperature) $\times$ Sorel-Tracy & 2.716 & 6.721 & $<0.001$
\end{tabular}

Deviance explained $=93 \%, n=93, R^{2}(\operatorname{adj})=0.92$

Note: All $p$ values are significant $(\alpha=0.05)$.

Table 4. Acclimation response ratios (ARR) between 18 and $26{ }^{\circ} \mathrm{C}$ as well as between 18 and $28{ }^{\circ} \mathrm{C}$ for four round goby populations acclimated for at least 30 days.

\begin{tabular}{lllll}
\hline & \multicolumn{3}{l}{ Population } & \\
\cline { 2 - 5 } Temperature $\left({ }^{\circ} \mathrm{C}\right)$ & Kingsville & Hamilton & Melocheville & Sorel-Tracy \\
\hline $18-26$ & 0.361 & 0.344 & 0.293 & 0.159 \\
$18-28$ & 0.321 & 0.356 & 0.0913 & 0.0678 \\
\hline
\end{tabular}

when acclimated to $28^{\circ} \mathrm{C}$; for these two populations, $\mathrm{CT}_{\max }$ may be highest around $25{ }^{\circ} \mathrm{C}$. These northern populations also reached their measured maxima at lower temperatures than the southern populations, with mean \pm SE tolerances of $34.06 \pm$ $0.19^{\circ} \mathrm{C}$ and $33.74 \pm 0.16^{\circ} \mathrm{C}$ for fish acclimated to $26^{\circ} \mathrm{C}$ from Melocheville and Sorel-Tracy, respectively.

The southern populations exhibited greater acclimation capacity than the northern populations. ARRs for the Kingsville and Hamilton gobies were higher than those for Melocheville and Sorel-Tracy between 18 and $26{ }^{\circ} \mathrm{C}$. Between 18 and $28{ }^{\circ} \mathrm{C}$, ARRs fell to nearly 0 for the northern populations, whereas the southern populations retained acclimation capacity (Table 4 ).
Table 5. Results of a GAM testing the effects of population, sex, acclimation temperature and fish mass on the maximum feeding rate of round goby.

\begin{tabular}{llcc}
\hline Parametric terms & df & F & $p$ value \\
\hline Population & 3 & 6.013 & $<\mathbf{0 . 0 1}$ \\
Sex & 1 & 10.386 & $<\mathbf{0 . 0 1}$ \\
& & & \\
\hline Smooth terms & edf & F & $p$ value \\
\hline$s$ (Temperature) $\times$ Kingsville & 1.001 & 9.215 & $<\mathbf{0 . 0 1}$ \\
$s$ (Temperature) $\times$ Hamilton & 1.603 & 5.876 & $<\mathbf{0 . 0 1}$ \\
$s$ (Temperature) $\times$ Melocheville & 2.463 & 5.382 & $<\mathbf{0 . 0 1}$ \\
$s$ (Temperature) $\times$ Sorel-Tracy & 2.386 & 6.736 & $<\mathbf{0 . 0 1}$ \\
$s$ (Fish mass) $\times$ Kingsville & 1.000 & 1.887 & 0.173 \\
$s$ (Fish mass) $\times$ Hamilton & 1.000 & 10.696 & $<\mathbf{0 . 0 1}$ \\
$s$ (Fish mass) $\times$ Melocheville & 1.001 & 17.697 & $<\mathbf{0 . 0 0 1}$ \\
$s$ (Fish mass) $\times$ Sorel-Tracy & 1.347 & 0.931 & 0.522
\end{tabular}

Deviance explained $=58 \%, n=109, R^{2}($ adj $)=0.51$

Note: Significant $p$ values $(\alpha=0.05)$ are bolded.

\section{Feeding behaviour and body condition}

Maximum feeding rate varied within and across populations (Table 5). Acclimation temperature had a significant effect on feeding rate for all populations. Feeding rates generally declined at the highest acclimation temperatures (Fig. 4) and were maximal at $18{ }^{\circ} \mathrm{C}$ for gobies from Kingsville, $22{ }^{\circ} \mathrm{C}$ for gobies from Hamilton and Sorel-Tracy, and $24{ }^{\circ} \mathrm{C}$ for gobies from Melocheville. The Sorel-Tracy population exhibited the lowest maximum feeding rates overall, with a mean \pm SE of $41.6 \pm 6.32$ prey items consumed across all acclimation temperatures, compared to means ranging from $68.2 \pm 7.97$ to $80.4 \pm 8.07$ prey items for the other three populations. Given the significant size difference between individuals from Sorel-Tracy and Melocheville, feeding rates were standardized by fish mass for further examination. The highest feeding rates observed across all treatments were in the Kingsville and Hamilton populations. When standardized by fish mass, Hamilton gobies had the greatest mean feeding rate 
Fig. 4. Maximum feeding rates (number of prey eaten, adjusted for fish mass with partial residuals) for four populations of round goby acclimated to $18,22,24$ (Melocheville and Sorel-Tracy), 26 or $28{ }^{\circ} \mathrm{C}$. Ribbons represent \pm 2 standard errors around the mean, derived from GAM analysis.

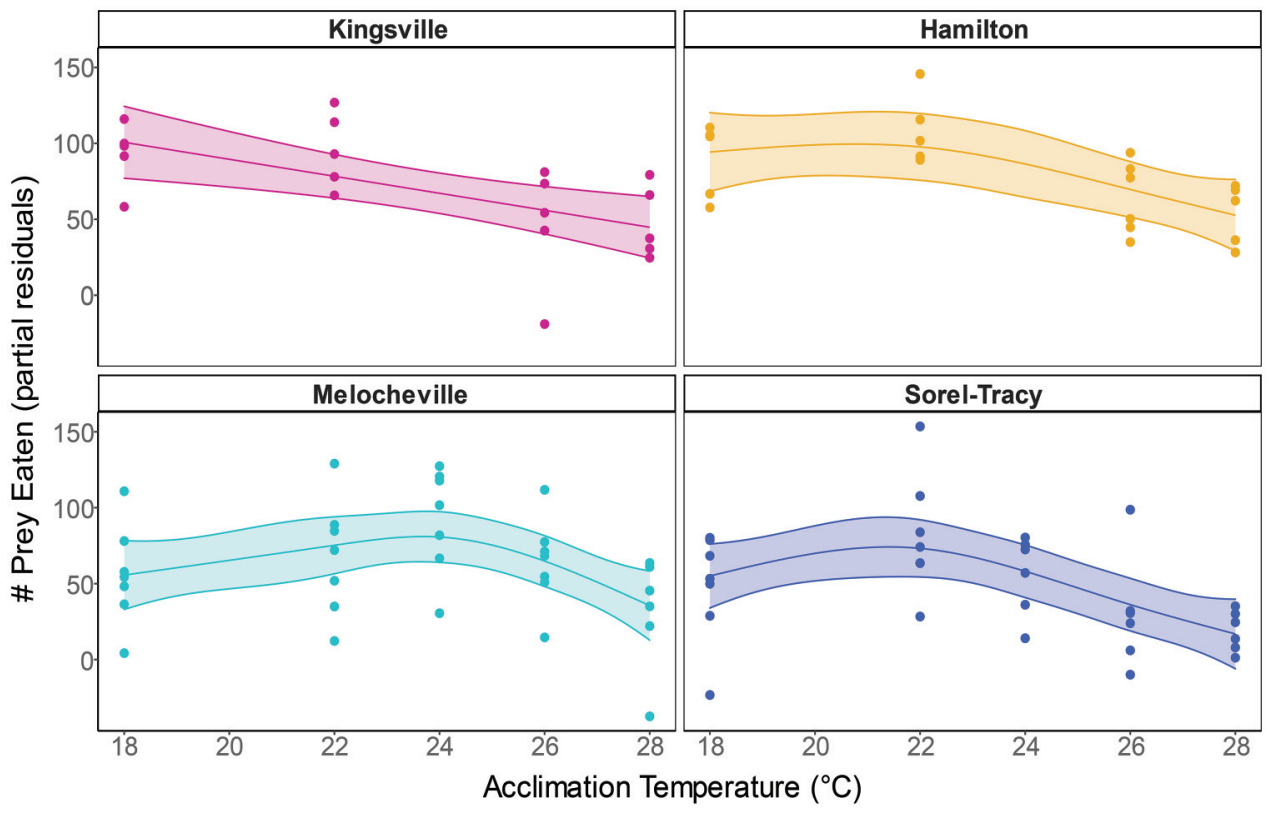

Table 6. Results of a GAM testing the effects of population and acclimation temperature on the body condition of round goby.

\begin{tabular}{lllc}
\hline Parametric term & $\mathrm{df}$ & $\mathrm{F}$ & $p$ value \\
\hline Population & 3 & 6.597 & $<\mathbf{0 . 0 0 1}$ \\
\hline Smooth terms & edf & F & $p$ value \\
\hline$s($ Temperature $) \times$ Kingsville & 1.000 & 0.393 & 0.532 \\
$s($ Temperature $) \times$ Hamilton & 2.635 & 2.620 & 0.0526 \\
$s($ Temperature $) \times$ Melocheville & 1.000 & 4.973 & $<\mathbf{0 . 0 5}$ \\
$s($ Temperature $) \times$ Sorel-Tracy & 1.156 & 1.478 & 0.277 \\
& & & \\
\hline Deviance explained $=27 \%, n=109, R^{2}($ adj $)=0.21$ \\
\hline \multicolumn{2}{c}{ Note: Significant $p$ values $(\alpha=0.05)$ are bolded. }
\end{tabular}

(11.6 \pm 0.62 prey items per gram fish) at $22^{\circ} \mathrm{C}$, followed by Kingsville gobies at $18{ }^{\circ} \mathrm{C}(11.1 \pm 1.22$ prey items per gram fish; Supplementary Table $\mathrm{S}^{1}$ ). Feeding rates increased with fish mass for the Hamilton and Melocheville populations (GAM: $p<0.01$ ), but did not significantly change with mass for Kingsville or Sorel-Tracy. Feeding rates were significantly affected by sex, with male fish generally consuming more prey items (GAM: $F=10.386, p<0.01$ ).

Body condition factor was highly variable across populations. Only fish from Melocheville showed significant changes in body condition with acclimation temperature (Table 6) and reached their lowest condition factor at $28{ }^{\circ} \mathrm{C}$ (Fig. 5). Body condition was highest for gobies from Hamilton (mean $K=1.29 \pm 0.023$ ) and Melocheville (1.32 \pm 0.019$)$, compared with those from Kingsville $(1.23 \pm 0.015)$ and Sorel-Tracy $\left(1.23 \pm 0.017\right.$; Supplementary Table S3 $\left.{ }^{1}\right)$.

\section{Discussion}

Our results demonstrated interpopulation variation in the responses of an invasive freshwater fish to temperature change. To our knowledge, this is the first study to detect a distinctly nonlinear $\mathrm{CT}_{\max }$ response to acclimation temperature in fish; the $\mathrm{CT}_{\max }$ of gobies from northern populations was found to eventually decline under elevated water temperatures, whereas those from more southerly populations within the basin did not exhibit the same decline. Differences such as these highlight the value of conducting studies on multiple conspecific populations.

\section{Critical thermal maximum and acclimation capacity}

As predicted, $\mathrm{CT}_{\max }$ changed significantly with acclimation temperature; all four populations increased their $\mathrm{CT}_{\max }$ when acclimated to $\leq 26{ }^{\circ} \mathrm{C}$, and the Kingsville and Hamilton populations increased their thermal tolerance further when acclimated to $28{ }^{\circ} \mathrm{C}$. Most freshwater fish species are able to adjust their $\mathrm{CT}_{\max }$ to higher temperatures with acclimation (Beitinger et al. 2000; Comte and Olden 2017). The ARR for mid-latitude fishes calculated by Morley et al. (2019) is approximately 0.35, whereas Beitinger et al. (2000) found a mean ARR of 0.41 for a selection of freshwater fishes. Therefore, Kingsville and Hamilton populations with ARRs of 0.321 and 0.356 , respectively, at $18-28^{\circ} \mathrm{C}$, have acclimation capacities similar to at least some other fishes occupying the same latitudes. Temperature acclimation allows ectotherms to shift their thermal windows in response to changes in temperature (MacLean et al. 2019), and phenotypic plasticity can mitigate the stress of rapid temperature shifts (Sandblom et al. 2014; Seebacher et al. 2015). The Kingsville and Hamilton populations are capable of successful acclimation to elevated temperatures and retain considerable acclimation capacity, such that they appear able to cope with anticipated thermal challenges due to climate change.

The two St. Lawrence River populations (Melocheville and Sorel-Tracy) showed responses to elevated temperatures that contrasted those of the lower Great Lakes populations. In addition to the lower thermal tolerance of round gobies from these populations, which was predicted, their ARRs suggest that they do not have the same capacity for acclimation as the southern populations. Where these populations diverge most is at the highest acclimation temperature; the tolerances of the northern populations were highest near $26^{\circ} \mathrm{C}$, with $\mathrm{CT}_{\max }$ for gobies acclimated to $28{ }^{\circ} \mathrm{C}$ declining to similar temperatures as that of gobies acclimated to 18 or $22^{\circ} \mathrm{C}$. Such declines in $\mathrm{CT}_{\max }$ with increasing acclimation temperature have not, to our knowledge, been recorded for other fishes. These responses suggest that between 26 and 
Fig. 5. Body condition factor $(K)$ for four populations of round goby acclimated to $18,22,24$ (Melocheville and Sorel-Tracy), 26 or $28{ }^{\circ} \mathrm{C}$. Ribbons represent \pm 2 standard errors around the mean, derived from GAM analysis.

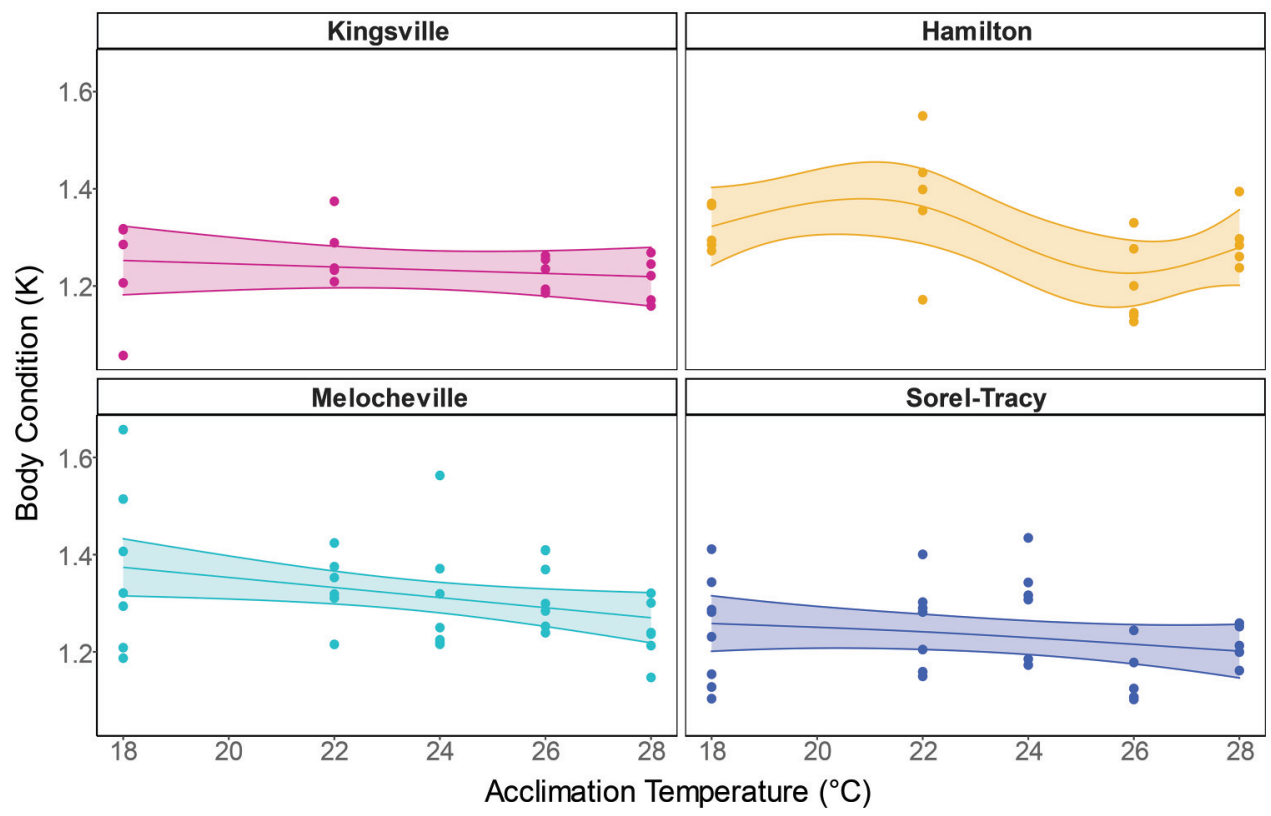

$28{ }^{\circ} \mathrm{C}$ there exists a crucial threshold for northern populations. Gobies from Sorel-Tracy were significantly smaller in size compared to those from Melocheville; yet they showed a similar, though less pronounced acclimation response, suggesting that these thresholds could apply to all adult gobies within these populations. Upper thermal limits appear to be largely unaffected by size differences for many adult freshwater fishes (Recsetar et al. 2012).

Sublethal thresholds in fishes are the points past which cellular processes are impaired such that whole-organism performance declines (Jeffries et al. 2018; Morrison et al. 2020). Performance is tied to biological processes such as metabolism, which typically increases with temperature as oxygen and energy demands increase (Pörtner and Farrell 2008; Schulte 2015). Acclimation can allow an organism to shift its thermal tolerance upward, but there are still physiological constraints that cannot be overcome, and prolonged exposure to high temperature can impose metabolic costs (Pörtner and Farrell 2008; Schulte 2014). Metabolic rates in multiple populations of round goby increase with temperature, particularly past $26^{\circ} \mathrm{C}$ (Lee and Johnson 2005; Drouillard et al. 2018; Christensen et al. 2021); therefore, at these elevated temperatures there are higher energetic demands placed on gobies, requiring physiological adjustment. In studies of brook trout (Salvelinus fontinalis), $\mathrm{CT}_{\max }$ has been found to plateau between 20 and $25{ }^{\circ} \mathrm{C}$, and molecular stress responses increase past $20{ }^{\circ} \mathrm{C}$ (Chadwick and McCormick 2017; Morrison et al. 2020). While $\mathrm{CT}_{\max }$ did not decline, brook trout apparently reached a physiological threshold beyond which metabolic demands and declining cell function impaired their acclimation capacity. In our study, $28{ }^{\circ} \mathrm{C}$ is probably close to the tolerance limit of round gobies from northern populations, with long-term exposure putting them consistently under stress. A similar threshold may exist for the southern populations at a higher temperature (e.g., $30^{\circ} \mathrm{C}$ ), but the plasticity in the observed thermal response points to differing vulnerabilities to warming between populations.

\section{Feeding behaviour and body condition}

Another way in which temperature governs the performance of a species is through its effects on feeding behaviour (e.g., Iacarella et al. 2015; Perello et al. 2015). Maximum feeding rates of round goby in this study were highest at temperatures $\leq 24{ }^{\circ} \mathrm{C}$. Lee and Johnson (2005) observed maximal food consumption by the round goby from western Lake Erie (in the same area as the Kingsville population in our study) and Lake St. Clair between 23 and $26{ }^{\circ} \mathrm{C}$, followed by a sharp decline. Feeding rate declines at high temperatures were observed in our study as well, though most populations (including Kingsville) consumed more food at 18 and $22{ }^{\circ} \mathrm{C}$ than at $26^{\circ} \mathrm{C}$, contrary to predictions. An organism's feeding efficiency and associated per capita effects on the environment are expected to occur under physiologically optimal environmental conditions (Iacarella et al. 2015); however, growth can be optimal at temperatures different from those at which organisms maximize their feeding, owing to differences in conversion efficiency (Hodgins et al. 2014). While growth was not measured in the adult round gobies used in this study, juveniles from Melocheville in a separate study in our lab were found to grow more at $18{ }^{\circ} \mathrm{C}$ than at $25{ }^{\circ} \mathrm{C}$ (G. D'Avignon, D. Wang, H. B. Reid, and A. Ricciardi, unpublished data). Feeding efficiency is likely greater at lower temperatures, at least in juveniles, with individuals better able to assimilate food and derive performance benefits. However, while adult Melocheville gobies fed more at $24{ }^{\circ} \mathrm{C}$ than at $18{ }^{\circ} \mathrm{C}$, the primary thermal effect appeared to be considerably lowered feeding rates at $28^{\circ} \mathrm{C}$. These results suggest that populations of round goby have different thermal optima for feeding; yet feeding performance declines at elevated temperatures in most cases, and there are potential benefits of feeding at lower temperatures. The significantly higher feeding rates of male fish could conceivably result from intraspecific competition dynamics, differences in boldness and aggression, or differential responses to stress in the holding aquaria (Ward et al. 2006; Chang et al. 2012). Another contributing factor might be the random allotment of more female fish to higher acclimation temperature treatments, as these had lower feeding rates overall across populations.

Overall, reduced feeding rates of round goby are likely due to performance trade-offs and behavioural changes associated with elevated temperatures. As described above, elevated metabolic rates have been measured at high temperatures $\left(\geq 26^{\circ} \mathrm{C}\right)$ in round goby (Lee and Johnson 2005; Drouillard et al. 2018; Christensen et al. 2021). Acclimation to stressful temperatures introduces 
trade-offs between maintaining metabolic function and resource acquisition (Schulte 2015) - such that as an organism's metabolism is driven higher, more energy is required for simple performance maintenance (Morley et al. 2019). For example, larger amounts of consumed food require more energy to digest, so fish might preferentially feed less to preserve energy for other uses (Norin and Clark 2017). This trade-off can lead to lower growth rates at higher temperatures, such as those observed in juvenile round gobies from Melocheville (G. D’Avignon, D. Wang, H. B. Reid, and A. Ricciardi, unpublished data). Adult round gobies from the nearby Sorel-Tracy population were significantly smaller than those from Melocheville, and experienced conspicuous feeding declines at elevated temperatures. While still adults, these slightly smaller fish from a more northern location might have had increased susceptibility to the deleterious effects of elevated temperatures. The vast majority $(95 \%)$ of round gobies acclimated to $28^{\circ} \mathrm{C}$ survived, so this temperature is not acutely lethal, but gobies were more readily infected by common parasites (e.g., Ichthyophthirius multifilis); this apparently diminished immune response lends further support for increased performance costs at elevated temperatures. Thermal stress also induces thermoregulatory behavioural responses that fish may prioritize over foraging (Drouillard et al. 2018; Zanuzzo et al. 2019). Round gobies might feed less at higher temperatures because they would normally expend their declining energy attempting to migrate to less thermally stressful areas (as observed in marine gobiids; Ford et al. 2004), which was not possible in our aquaria.

Non-native animals that consume greater amounts of resources are more likely to cause negative trophic impacts on their invaded community (Ricciardi et al. 2013). The temperatures at which they forage most effectively are likely to be those at which their consumptive effects are greatest (Iacarella et al. 2015). The highest feeding rates in this study were observed in gobies from the Kingsville and Hamilton populations at the lower temperatures. Gobies acclimated to the two lowest temperatures (18 and $22{ }^{\circ} \mathrm{C}$ ) from Kingsville and Hamilton consumed a mean \pm SE of $10.9 \pm 1.23$ and $11 \pm 0.96$ prey items per gram of fish, respectively, whereas those from Melocheville consumed a mean \pm SE of $6.6 \pm$ 1.38 prey items per gram of fish and those from Sorel-Tracy consumed $7.9 \pm 1.56$ items per gram of fish across the same temperatures. Gobies from Kingsville had the same mean body condition as those from Sorel-Tracy $(K=1.23 \pm 0.015)$ and still fed more than this population and Melocheville $(1.29 \pm 0.023)$. Body condition in this study was variable within treatments, but generally fell within a narrow margin $(K=1.2-1.4)$. Given that a higher body condition is typically associated with greater energy reserves and health (Mozsár et al. 2015), the Kingsville and Sorel-Tracy populations had marginally lower fitness. In addition, feeding rates did not significantly increase with increasing fish mass in these two populations. Nevertheless, Kingsville gobies maintained higher feeding rates on par with those of the more fit Hamilton fish.

\section{Habitat temperatures}

The four locations examined in this study generally followed expected latitudinal patterns in water temperature, with the southernmost location (Toledo, used as a proxy for Kingsville, Lake Erie) having the highest mean summer temperatures overall $\left(23.57 \pm 0.34{ }^{\circ} \mathrm{C}\right)$ and the northernmost location (Sorel-Tracy) having the lowest temperatures $\left(21.08 \pm 0.42{ }^{\circ} \mathrm{C}\right)$. In nearshore habitats of Lakes Erie and Ontario in particular, water temperatures are already quite high for extended periods of time in the summer. These lakes have experienced considerable warming in recent decades (Dobiesz and Lester 2009; Trumpickas et al. 2009; Mason et al. 2016). From July to early September 2020, mean temperatures in Toledo were near or above $25^{\circ} \mathrm{C}$, and temperatures in Hamilton were often not much lower. In the summer of 2020 , mean daily temperatures reached or exceeded $25{ }^{\circ} \mathrm{C}$ in Toledo and Hamilton for 59 and 32 days, respectively. Trumpickas et al.
(2009) predicted that the 20th highest temperature observed would be at least 24.7 and $23.8{ }^{\circ} \mathrm{C}$ for Lakes Erie and Ontario, respectively, from 2041 to 2070 ; these projections are $1.5^{\circ} \mathrm{C}$ (Lake Erie) and $2.2^{\circ} \mathrm{C}$ (Lake Ontario) higher than corresponding temperatures from 1971 to 2000 . Based on our results, these future projections have already been met or exceeded in nearshore areas, suggesting that climate warming is outpacing model predictions.

All nearshore areas in this study experienced summer temperatures similar to those tested in our experiments. Temperatures at both Toledo and Hamilton approached $30{ }^{\circ} \mathrm{C}$, whereas the northern locations typically reached slightly lower extremes; Cootes Paradise, adjacent to Hamilton Harbour, had logged temperatures up to $32.26{ }^{\circ} \mathrm{C}$. High temperatures such as these are stressful, or even fatal, for many freshwater fish species and can prompt behavioural and physiological responses (Abram et al. 2017). Consequently, nearshore locations could soon become inhospitable to many species, driving them into deeper waters (Ebersole et al. 2020). Whereas deeper locations are more buffered against temperature fluctuations and extremes, and can provide thermal refugia for fish and mobile prey (Sotiropoulos et al. 2006), littoral areas are crucial for spawning and feeding, and act as refugia from predation (Winfield 2004). A number of species migrate between littoral and deeper waters daily or seasonally, in accordance with their preferences (Winfield 2004); for example, burbot (Lota lota) prefer colder waters, and move out of nearshore areas during the summer (Fischer and Eckmann 1997). However, extended warming trends can erode thermal refugia (Dobiesz and Lester 2009; Davis et al. 2013). Native and non-native populations that can acclimate successfully to higher temperatures should therefore have competitive advantages under climate change.

\section{Implications for performance under climate warming}

Temperature tolerances in freshwater fishes are partly determined by the environmental conditions they experience (Comte and Olden 2017) and, therefore, thermal responses can vary between climatically distinct locations (Baudier et al. 2018; MacLean et al. 2019). At broad scales, species from locations with more homogeneous thermal conditions (e.g., low-latitude locations) are expected to have reduced acclimation capacity, because a history of exposure to a narrow range of temperatures results in lower adaptive potential (Tewksbury et al. 2008; Rohr et al. 2018). In midlatitude locations, which are typically characterized by seasonal temperature variation, latitudinal differences in $\mathrm{CT}_{\max }$ have been observed in freshwater fishes such as channel catfish (Ictalurus punctatus; Stewart and Allen 2014) and brook trout (S. fontinalis; Stitt et al. 2014), with populations of more southerly origins having increased tolerance. In our study, the observed thermal tolerance patterns were similar to those of other mid-latitude fishes; while both northern sites reached high temperatures during the summer, extended periods of elevated temperatures were not recorded at these sites, unlike in the lower Great Lakes. Although southern populations are exposed to elevated temperatures more frequently, climate change could drive warming trends throughout the basin at higher rates than predicted. Round gobies in the St. Lawrence River might not have adequate thermal history or capacity to tolerate continued warming. These northern populations are more intolerant of elevated temperatures, have lower plasticity, and feed less overall; therefore, their trophic impacts could diminish as warming accelerates. Alternatively, these populations could plausibly be replaced by warm-adapted gobies migrating north.

Interpopulation variation manifesting over such a short time period (30 years or less) in the round goby's non-native North American range has implications for the ability of invasive species to locally adapt or acclimate to novel conditions. The Kingsville and Hamilton populations have similar thermal responses. These populations are connected via the Welland Canal, which 
circumvents Niagara Falls, so their shared traits might result from natural migration or human-mediated dispersal. However, dispersal following round goby establishment is thought to be minimal, at least for the last decade (Johansson et al. 2018). Significant genetic variation in round gobies throughout the Great Lakes and the St. Lawrence River (Brown and Stepien 2009), coupled with low dispersal rates, is potentially sufficient to drive local adaptation, though this requires further examination (Hoffmann and Sgrò 2011; Schulte 2014). In addition to potential evolutionary adaptation, some populations established in the lower Great Lakes could have inherently greater thermal plasticity, or they experience selection pressures that favour more plastic phenotypes than in the St. Lawrence River (Hoffmann and Sgrò 2011; Seebacher et al. 2015). In any case, round gobies in the lower Great Lakes appear to be significantly more thermally tolerant than their counterparts in the St. Lawrence River, as well as at least one population in Denmark (Christensen et al. 2021). Successful invaders in general are expected to have broader tolerances and higher acclimation capacity, allowing them to overcome abiotic environmental barriers to establishment and subsequent population expansion (Kelley 2014). Some invasive fish populations appear to have higher thermal plasticity or be capable of rapidly adapting to novel conditions - traits that can shape their responses to climate change.

Assessing an invader's impacts in an era of climate change requires accurate data on its temperature tolerances and optima (Ricciardi et al. 2021). Our study shows that the thermal responses of an invasive species can differ substantially across a subcontinental region. Intraspecific variation in thermal tolerance has been observed in many fishes distributed across spatial scales (Fangue et al. 2006; Stewart and Allen 2014; Stitt et al. 2014), drawing increasing attention to the roles of local adaptation, acclimation, and plasticity in shaping differential responses at the population level (Schulte 2014; Herrando-Pérez et al. 2019). It is therefore potentially misleading to predict species' responses to climate change based on a single population. Greater resolution of thermal ecology data that accounts for population variation will allow for more accurate risk assessment and thus better targeted management actions.

\section{Acknowledgements}

We are grateful to Jessamine Trueman and Geneviève D'Avignon for their valuable feedback on methodology and their assistance with field and lab work. Additional assistance in the field and laboratory was provided by Nikki Moore, Paul Bzonek, Kunali Gohil, Philippe Hénault, Meagan Kindree, Dave Marson, Giulio Navarroli, Hélène Pfister, Elliott Quider, and Duncan Wang. We thank Nick Mandrak for providing laboratory space and commenting on the manuscript. This research was funded by a Strategic Project Grant (NSERC STPGP 506528-17) to AR from the Natural Sciences and Engineering Research Council of Canada.

\section{References}

Abram, P.K., Boivin, G., Moiroux, J., and Brodeur, J. 2017. Behavioural effects of temperature on ectothermic animals: unifying thermal physiology and behavioural plasticity: effects of temperature on animal behaviour. Biol. Rev. 92(4): 1859-1876. doi:10.1111/brv.12312. PMID:28980433.

Adrian-Kalchhauser, I., Blomberg, A., Larsson, T., Musilova, Z., Peart, C.R., Pippel, M., et al. 2020. The round goby genome provides insights into mechanisms that may facilitate biological invasions. BMC Biol. 18: 11. doi:10.1186/ s12915-019-0731-8. PMID:31992286.

Austin, J.A., and Colman, S.M. 2007. Lake Superior summer water temperatures are increasing more rapidly than regional air temperatures: a positive icealbedo feedback. Geophys. Res. Lett. 34(6): L06604. doi:10.1029/2006GL029021.

Bartolai, A.M., He, L., Hurst, A.E., Mortsch, L., Paehlke, R., and Scavia, D. 2015. Climate change as a driver of change in the Great Lakes St. Lawrence River Basin. J. Great Lakes Res. 41: 45-58. doi:10.1016/j.jglr.2014.11.012.

Baudier, K.M., D'Amelio, C.L., Malhotra, R., O'Connor, M.P., and O'Donnell, S. 2018. Extreme insolation: climatic variation shapes the evolution of thermal tolerance at multiple scales. Am. Nat. 192(3): 347-359. doi:10.1086/698656. PMID:30125235.

Becker, C.D., and Genoway, R.G. 1979. Evaluation of the critical thermal maximum for determining thermal tolerance of freshwater fish. Environ. Biol. Fish. 4(3): 245-256. doi:10.1007/BF00005481.

Beitinger, T.L., Bennett, W.A., and McCauley, R.W. 2000. Temperature tolerances of North American freshwater fishes exposed to dynamic changes in temperature. Environ. Biol. Fishes, 58: 237-275. doi:10.1023/A:1007676325825.

Bolger, T., and Connolly, P.L. 1989. The selection of suitable indices for the measurement and analysis of fish condition. J. Fish Biol. 34(2): 171-182. doi:10.1111/j.1095-8649.1989.tb03300.x.

Brandner, J., Cerwenka, A.F., Schliewen, U.K., and Geist, J. 2018. Invasion strategies in round goby (Neogobius melanostomus): Is bigger really better? PLoS ONE, 13(1): e0190777. doi:10.1371/journal.pone.0190777. PMID:29304159.

Brown, J.E., and Stepien, C.A. 2009. Invasion genetics of the Eurasian round goby in North America: tracing sources and spread patterns. Mol. Ecol. 18(1): 64-79. doi:10.1111/j.1365-294X.2008.04014.x. PMID:19140965.

Burkett, E.M., and Jude, D.J. 2015. Long-term impacts of invasive round goby Neogobius melanostomus on fish community diversity and diets in the St. Clair River, Michigan. J. Great Lakes Res. 41(3): 862-872. doi:10.1016/j.jglr.2015. 05.004

Carline, R.F., and Machung, J.F. 2001. Critical thermal maxima of wild and domestic strains of trout. Trans. Am. Fish Soc. 130(6): 1211-1216. doi:10.1577| 1548-8659(2001)130<1211:CTMOWA $>2.0$. CO;2.

Chadwick, J.G., and McCormick, S.D. 2017. Upper thermal limits of growth in brook trout and their relationship to stress physiology. J. Exp. Biol. 220(21): 3976-3987. doi:10.1242/jeb.161224. PMID:29093190.

Chang, C., Li, C.-Y., Earley, R.L., and Hsu, Y. 2012. Aggression and related behavioral traits: the impact of winning and losing and the role of hormones. Integr. Comp. Biol. 53(6): 801-813, doi:10.1093/icb/ics057.

Charlebois, P.M., Corkum, L.D., Jude, D.J., and Knight, C. 2001. The round goby (Neogobius melanostomus) invasion: current research and future needs. J. Great Lakes Res. 27(3): 263-266. doi:10.1016/S0380-1330(01)70641-7.

Chen, Z., Anttila, K., Wu, J., Whitney, C.K., Hinch, S.G., and Farrell, A.P. 2013. Optimum and maximum temperatures of sockeye salmon (Oncorhynchus nerka) populations hatched at different temperatures. Can. J. Zool. 91(5): 265274. doi:10.1139/cjz-2012-0300.

Christensen, E.A.F., Norin, T., Tabak, I., van Deurs, M., and Behrens, J.W. 2021. Effects of temperature on physiological performance and behavioral thermoregulation in an invasive fish, the round goby. J. Exp. Biol. 224: jeb237669. doi:10.1242/jeb.237669. PMID:33257434.

Claussen, D.L. 1977. Thermal acclimation in ambystomatid salamanders. Comp. Biochem. Physiol. A Mol. Integr. Physiol. 58(4): 333-340. doi:10.1016/ 0300-9629(77)90150-5.

Collingsworth, P.D., Bunnell, D.B., Murray, M.W., Kao, Y.-C., Feiner, Z.S., Claramunt, R.M., et al. 2017. Climate change as a long-term stressor for the fisheries of the Laurentian Great Lakes of North America. Rev. Fish Biol. Fish. 27(2): 363-391. doi:10.1007/s11160-017-9480-3.

Comte, L., and Olden, J.D. 2017. Evolutionary and environmental determinants of freshwater fish thermal tolerance and plasticity. Glob. Change Biol. 23(2): 728-736. doi:10.1111/gcb.13427.

Corkum, L.D., Sapota, M.R., and Skora, K.E. 2004. The round goby, Neogobius melanostomus, a fish invader on both sides of the Atlantic Ocean. Biol. Invasions, 6(2): 173-181. doi:10.1023/B:BINV.0000022136.43502.db.

Cross, E.E., and Rawding, R.S. 2009. Acute thermal tolerance in the round goby, Apollonia melanostoma (Neogobius melanostomus). J. Therm. Biol. 34(2): 85-92. doi:10.1016/j.jtherbio.2008.10.006.

David, P., Thébault, E., Anneville, O., Duyck, P.-F., Chapuis, E., and Loeuille, N. 2017. Impacts of invasive species on food webs: a review of empirical data. In Networks of Invasions: A Synthesis of Concepts. Edited by D.A. Bohan, A.J. Dumbrell, and F. Massol. Academic Press, Cambridge, UK. pp. 1-60. doi:10.1016/bs.aecr.2016.10.001.

Davis, J., Pavlova, A., Thompson, R., and Sunnucks, P. 2013. Evolutionary refugia and ecological refuges: key concepts for conserving Australian arid zone freshwater biodiversity under climate change. Glob. Change Biol. 19(7): 1970-1984. doi:10.1111/gcb.12203.

Dobiesz, N.E., and Lester, N.P. 2009. Changes in mid-summer water temperature and clarity across the Great Lakes between 1968 and 2002. J. Great Lakes Res. 35(3): 371-384. doi:10.1016/j.jglr.2009.05.002.

Drouillard, K.G., Feary, D.A., Sun, X., O’Neil, J.A., Leadley, T., and Johnson, T.B. 2018. Comparison of thermal tolerance and standard metabolic rate of two Great Lakes invasive fish species. J. Great Lakes Res. 44(3): 476-481. doi:10.1016/j.jglr.2018.02.010.

Ebersole, J.L., Quiñones, R.M., Clements, S., and Letcher, B.H. 2020. Managing climate refugia for freshwater fishes under an expanding human footprint. Front. Ecol. Environ. 18(5): 271-280. doi:10.1002/fee.2206. PMID:32944010.

Fangue, N.A., Hofmeister, M., and Schulte, P.M. 2006. Intraspecific variation in thermal tolerance and heat shock protein gene expression in common killifish, Fundulus heteroclitus. J. Exp. Biol. 209(15): 2859-2872. doi:10.1242/ jeb.02260. PMID:16857869.

Fischer, P., and Eckmann, R. 1997. Seasonal changes in fish abundance, biomass and species richness in the littoral zone of a large European lake, Lake Constance, Germany. Arch. Hydrobiol. 139(4): 433-448. doi:10.1127/archiv-hydrobiol/ $139 / 1997 / 433$. 
Florin, A.-B., Reid, D., Sundblad, G., and Näslund, J. 2018. Local conditions affecting current and potential distribution of the invasive round goby - species distribution modelling with spatial constraints. Estuar. Coast. Shelf Sci. 207: 359-367. doi:10.1016/j.ecss.2017.10.005.

Ford, J.M.J., Tibbetts, I.R., and Carseldine, L. 2004. Ventilation rate and behavioural responses of two species of intertidal goby (Pisces: Gobiidae) at extremes of environmental temperature. Hydrobiologia, 528: 63-73. doi:10.1007/s10750004-2408-7.

Hatton, E.C., Buckley, J.D., Fera, S., Hunt, L.M., and Drake, D.A.R., and Johnson, T.B. 2018. Ecological temperature metrics for invasive fishes in Ontario and the Great Lakes Region. Science and Research Information Report IR-15. Ontario Ministry of Natural Resources and Forestry, Peterborough, Ont.

Hellmann, J.J., Byers, J.E., Bierwagen, B.G., and Dukes, J.S. 2008. Five potential consequences of climate change for invasive species. Conserv. Biol. 22(3): 534-543. doi:10.1111/j.1523-1739.2008.00951.x. PMID:18577082.

Herrando-Pérez, S., Ferri-Yáñez, F., Monasterio, C., Beukema, W., Gomes, V., Belliure, J., et al. 2019. Intraspecific variation in lizard heat tolerance alters estimates of climate impact. J. Anim. Ecol. 88(2): 247-257. doi:10.1111/ 1365-2656.12914. PMID:30303530.

Hodgins, N.C., Schramm, H.L. Jr., and Gerard, P.D. 2014. Food consumption and growth rates of juvenile black carp fed natural and prepared feeds. J. Fish Wildl. Manag. 5(1): 35-45. doi:10.3996/112012-JFWM-101.

Hoffmann, A.A., and Sgrò, C.M. 2011. Climate change and evolutionary adaptation. Nature, 470(7335): 479-485. doi:10.1038/nature09670. PMID:21350480.

Huey, R.B., and Stevenson, R.D. 1979. Integrating thermal physiology and ecology of ectotherms: a discussion of approaches. Am. Zool. 19(1): 357366. doi:10.1093/icb/19.1.357.

Iacarella, J.C., Dick, J.T.A., Alexander, M.E., and Ricciardi, A. 2015. Ecological impacts of invasive alien species along temperature gradients: testing the role of environmental matching. Ecol. Appl. 25(3): 706-716. doi:10.1890/140545.1.

Jeffries, K.M., Fangue, N.A., and Connon, R.E. 2018. Multiple sub-lethal thresholds for cellular responses to thermal stressors in an estuarine fish. Comp. Biochem. Physiol. A Mol. Integr. Physiol. 225: 33-45. doi:10.1016/j. cbpa.2018.06.020. PMID:29958996.

Johansson, M.L., Dufour, B.A., Wellband, K.W., Corkum, L.D., MacIsaac, H.J., and Heath, D.D. 2018. Human-mediated and natural dispersal of an invasive fish in the eastern Great Lakes. Heredity, 120(6): 533-546. doi:10.1038/s41437017-0038-x. PMID:29317757.

Jude, D.J., Reider, R.H., and Smith, G.R. 1992. Establishment of Gobiidae in the Great Lakes Basin. Can. J. Fish. Aquat. Sci. 49(2): 416-421. doi:10.1139/ f92-047.

Kelley, A.L. 2014. The role thermal physiology plays in species invasion. Conserv. Physiol. 2(1): cou045. doi:10.1093/conphys/cou045. PMID:27293666.

Kipp, R., and Ricciardi, A. 2012. Impacts of the Eurasian round goby (Neogobius melanostomus) on benthic communities in the upper St. Lawrence River. Can. J. Fish. Aquat. Sci. 69(3): 469-486. doi:10.1139/f2011-139.

Kipp, R., Hébert, I., Lacharité, M., and Ricciardi, A. 2012. Impacts of predation by the Eurasian round goby (Neogobius melanostomus) on molluscs in the upper St. Lawrence River. J. Great Lakes Res. 38(1): 78-89. doi:10.1016/ j.jglr.2011.11.012.

Kornis, M.S., and Vander Zanden, M.J. 2010. Forecasting the distribution of the invasive round goby (Neogobius melanostomus) in Wisconsin tributaries to Lake Michigan. Can. J. Fish. Aquat. Sci. 67(3): 553-562. doi:10.1139/F10-002.

Kornis, M.S., Mercado-Silva, N., and Vander Zanden, M.J. 2012. Twenty years of invasion: a review of round goby Neogobius melanostomus biology, spread and ecological implications. J. Fish Biol. 80(2): 235-285. doi:10.1111/ j.1095-8649.2011.03157.x. PMID:22268429.

Kornis, M.S., Weidel, B.C., and Vander Zanden, M.J. 2017. Divergent life histories of invasive round gobies (Neogobius melanostomus) in Lake Michigan and its tributaries. Ecol. Freshw. Fish. 26(4): 563-574. doi:10.1111/eff.12300.

Lee, V.A., and Johnson, T.B. 2005. Development of a bioenergetics model for the round goby (Neogobius melanostomus). J. Great Lakes Res. 31(2): 125234. doi:10.1016/S0380-1330(05)70244-6.

MacLean, H.J., Sørensen, J.G., Kristensen, T.N., Loeschcke, V., Beedholm, K., Kellermann, V., and Overgaard, J. 2019. Evolution and plasticity of thermal tolerance: an analysis of variation in thermal tolerance and fitness in 22 Drosophila species. Phil. Trans. R. Soc. B, 374(1778): 20180548. doi:10.1098/ rstb.2018.0548. PMID:31203763.

Mainka, S.A., and Howard, G.W. 2010. Climate change and invasive species: double jeopardy. Integr. Zool. 5(2): 102-111. doi:10.1111/j.1749-4877.2010.00193.x. PMID:21392328.

Mason, L.A., Riseng, C.M., Gronewold, A.D., Rutherford, E.S., Wang, J., Clites, A., et al. 2016. Fine-scale spatial variation in ice cover and surface temperature trends across the surface of the Laurentian Great Lakes. Clim. Change, 138(1-2): 71-83. doi:10.1007/s10584-016-1721-2.

Matern, S.A. 2001. Using temperature and salinity tolerances to predict the success of the Shimofuri goby, a recent invader into California. Trans. Am. Fish Soc. 130(4): 592-599. doi:10.1577/1548-8659(2001)130<0592:UTASTT $>2.0$. $\mathrm{CO} ; 2$.

Mills, E.L., Leach, J.H., Carlton, J.T., and Secor, C.L. 1993. Exotic species in the Great Lakes: a history of biotic crises and anthropogenic introductions. J. Great Lakes Res. 19(1): 1-54. doi:10.1016/S0380-1330(93)71197-1.
Morley, S.A., Peck, L.S., Sunday, J.M., Heiser, S., and Bates, A.E. 2019. Physiological acclimation and persistence of ectothermic species under extreme heat events. Global Ecol. Biogeogr. 28(7): 1018-1037. doi:10.1111/geb.12911.

Morrison, S.M., Mackey, T.E., Durhack, T., Jeffrey, J.D., Wiens, L.M., Mochnacz, N.J., et al. 2020. Sub-lethal temperature thresholds indicate acclimation and physiological limits in brook trout Salvelinus fontinalis. J. Fish Biol. 97(2): 583-587. doi:10.1111/jfb.14411. PMID:32447755.

Mozsár, A., Boros, G., Sály, P., Antal, L., and Nagy, S.A. 2015. Relationship between Fulton's condition factor and proximate body composition in three freshwater fish species. J. Appl. Ichthyol. 31(2): 315-320. doi:10.1111/ jai.12658.

Myles-Gonzalez, E., Burness, G., Yavno, S., Rooke, A., and Fox, M.G. 2015. To boldly go where no goby has gone before: boldness, dispersal tendency, and metabolism at the invasion front. Behav. Ecol. 26(4): 1083-1090. doi:10.1093/beheco/arv050.

Norin, T., and Clark, T.D. 2017. Fish face a trade-off between 'eating big' for growth efficiency and 'eating small' to retain aerobic capacity. Biol. Lett. 13(9): 20170298. doi:10.1098/rsbl.2017.0298. PMID:28931728.

Perello, M., Simon, T., Thompson, H., and Kane, D. 2015. Feeding ecology of the invasive round goby, Neogobius melanostomus (Pallas, 1814), based on laboratory size preference and field diet in different habitats in the western basin of Lake Erie. Aquat. Invasions, 10(4): 463-474. doi:10.3391/ai.2015. 10.4.09.

Pörtner, H.O., and Farrell, A.P. 2008. Physiology and climate change. Science, 322(5902): 690-692. doi:10.1126/science.1163156. PMID:18974339.

Pörtner, H.O., Bennett, A.F., Bozinovic, F., Clarke, A., Lardies, M.A., Lucassen, M., et al. 2006. Trade-offs in thermal adaptation: the need for a molecular to ecological integration. Physiol. Biochem. Zool. 79(2): 295-313. doi:10.1086/499986. PMID:16555189.

QGIS Development Team. 2020. QGIS Geographic Information System. Open Source Geospatial Foundation. Available from http://qgis.org.

Radchuk, V., Reed, T., Teplitsky, C., van de Pol, M., Charmantier, A., Hassall, C., et al. 2019. S. 2019. Adaptive responses of animals to climate change are most likely insufficient. Nat. Commun. 10(1): 3109. doi:10.1038/s41467-019-10924-4. PMID:31337752.

Rahel, F.J., and Olden, J.D. 2008. Assessing the effects of climate change on aquatic invasive species. Conserv. Biol. 22(3): 521-533. doi:10.1111/j.15231739.2008.00950.x. PMID:18577081.

R Core Team. 2020. R: a language and environment for statistical computing. R Foundation for Statistical Computing, Vienna, Austria.

Recsetar, M.S., Zeigler, M.P., Ward, D.L., Bonar, S.A., and Caldwell, C.A. 2012. Relationship between fish size and upper thermal tolerance. Trans. Am. Fish. Soc. 141(6): 1433-1438. doi:10.1080/00028487.2012.694830.

Ricciardi, A. 2006. Patterns of invasion in the Laurentian Great Lakes in relation to changes in vector activity. Divers. Distrib. 12(4): 425-433. doi:10.1111/j.1366-9516.2006.00262.x.

Ricciardi, A., Hoopes, M.F., Marchetti, M.P., and Lockwood, J.L. 2013. Progress toward understanding the ecological impacts of nonnative species. Ecol. Monogr. 83(3): 263-282. doi:10.1890/13-0183.1.

Ricciardi, A., Iacarella, J.C., Aldridge, D.C., Blackburn, T.M., Carlton, J.T., Catford, J.A., et al. 2021. Four priority areas to advance invasion science in the face of rapid environmental change. Environ. Rev. 29(2): 119-141. doi:10.1139/er-2020-0088.

Robinson, T.B., Havenga, B., van der Merwe, M., and Jackson, S. 2017. Mind the gap - context dependency in invasive species impacts: a case study of the ascidian Ciona robusta. NeoBiota, 32: 127-141. doi:10.3897/neobiota.32.9373.

Rohr, J.R., Civitello, D.J., Cohen, J.M., Roznik, E.A., Sinervo, B., and Dell, A.I. 2018. The complex drivers of thermal acclimation and breadth in ectotherms. Ecol. Lett. 21(9): 1425-1439. doi:10.1111/ele.13107. PMID:30009486.

Sandblom, E., Gräns, A., Axelsson, M., and Seth, H. 2014. Temperature acclimation rate of aerobic scope and feeding metabolism in fishes: implications in a thermally extreme future. Proc. R. Soc. B, 281(1794): 20141490. doi:10.1098/rspb.2014.1490. PMID:25232133.

Schulte, P.M. 2014. What is environmental stress? Insights from fish living in a variable environment. J. Exp. Biol. 217(1): 23-34. doi:10.1242/jeb.089722. PMID:24353201.

Schulte, P.M. 2015. The effects of temperature on aerobic metabolism: towards a mechanistic understanding of the responses of ectotherms to a changing environment. J. Exp. Biol. 218(12): 1856-1866. doi:10.1242/ jeb.118851. PMID:26085663.

Seebacher, F., White, C.R., and Franklin, C.E. 2015. Physiological plasticity increases resilience of ectothermic animals to climate change. Nat. Clim. Change, 5(1): 61-66. doi:10.1038/nclimate2457.

Sotiropoulos, J.C., Nislow, K.H., and Ross, M.R. 2006. Brook trout, Salvelinus fontinalis, microhabitat selection and diet under low summer stream flows. Fish. Manage. 13(3): 149-155. doi:10.1111/j.1365-2400.2006.00487.x.

Stewart, H.A., and Allen, P.J. 2014. Critical thermal maxima of two geographic strains of channel and hybrid catfish. N. Am. J. Aquac. 76(2): 104111. doi:10.1080/15222055.2013.856827.

Stitt, B.C., Burness, G., Burgomaster, K.A., Currie, S., McDermid, J.L., and Wilson, C.C. 2014. Intraspecific variation in thermal tolerance and acclimation capacity in brook trout (Salvelinus fontinalis): physiological implications for climate change. Physiol. Biochem. Zool. 87(1): 15-29. doi:10.1086/675259. PMID: 24457918. 
Tewksbury, J.J., Huey, R.B., and Deutsch, C.A. 2008. Putting the heat on tropical animals. Science, 320(5881): 1296-1297. doi:10.1126/science.1159328. PMID:18535231.

Trumpickas, J., Shuter, B.J., and Minns, C.K. 2009. Forecasting impacts of climate change on Great Lakes surface water temperatures. J. Great Lakes Res. 35(3): 454-463. doi:10.1016/j.jglr.2009.04.005.

Ward, A.J.W., Webster, M.M., and Hart, P.J.B. 2006. Intraspecific food competition in fishes. Fish Fish. 7(4): 231-261. doi:10.1111/j.1467-2979.2006.00224.X.
Winfield, I.J. 2004. Fish in the littoral zone: ecology, threats and management. Limnologica, 34(1-2): 124-131. doi:10.1016/S0075-9511(04)80031-8.

Zanuzzo, F.S., Bailey, J.A., Garber, A.F., and Gamperl, A.K. 2019. The acute and incremental thermal tolerance of Atlantic cod (Gadus morhua) families under normoxia and mild hypoxia. Comp. Biochem. Physiol. A Mol. Integr. Physiol. 233: 30-38. doi:10.1016/j.cbpa.2019.03.020. PMID:30930205. 